\title{
POTENTIAL OF FOREIGN LANGUAGE LESSONS IN THE FORMATION OF SOCIALLY ACTIVE CIVIL COMPETENCE IN STUDENTS
}

Turdibay Jaliev

Researcher Karakalpak State University Named After Berdakh, Uzbekistan

\section{ABSTRACT}

The article describes the work on the formation of socially active civic competence. The process of assimilation and understanding by students of the concept of citizenship depends on the degree of their involvement in cognitive and socially useful activities. Students who have a fairly complete understanding of civic competence often do not see the possibilities of applying this quality in life, where their intervention and assistance is most needed. To solve the set tasks, a technology for the formation of socially active civic competence is proposed.

KEYWORDS: - Teacher, student, socially active civic competence, civic competence, activity, language, knowledge, process, formation.

\section{INTRODUCTION}

The most important component of the educational process in modern higher education is the formation of socially active civic competence, which are of great importance in the social, civic and spiritual development of the student's personality. Analysis of the experience of teachers showed that the formation of socially active civic competence occurs, as a rule, during general university, extracurricular and extracurricular activities. The potential of educational activities is not fully utilized. Each object must fulfill an educational function. Teaching a foreign language also has great opportunities in the formation of national and multicultural consciousness. Both of these tasks of the educational process are intertwined and successfully combined precisely in the lessons of a foreign language.

\section{THE MAIN RESULTS AND FINDINGS}

In order to identify ways to use educational activities in the formation of socially active civic competence, we have carried out experimental work. The task of the ascertaining experiment was to determine the level of formation of socially active civic competence. The main methods of obtaining initial data were questionnaires, observation, testing, conversations with teachers. We studied the following parameters:

- development of behavior skills in a multicultural environment in accordance with international norms and traditions;

- the level of formation of a sense of citizenship;

- the level of basic polytechnic, economic, 
CURRENT RESEARCH JOURNAL OF PEDAGOGICS 2(8): 63-67, August

2021 DOI: https://doi.org/10.37547/pedagogics-crjp-02-08-14

ISSN 2767-3278

(C)2021 Master Journals

\section{Crossref do) 81 Google}

Accepted 26 $6^{\text {th }}$ August, 2021 \& Published 31 $1^{\text {th }}$ August, 2021

sociological knowledge.

The analysis of the results obtained allows us to assert that the study of the problems of socially active civic competence is interesting to almost all participants in the experiment. The vast majority of students want to learn the basics of civic competence. This fact is justified by a linguistic orientation.

To determine the socially active civic competence of students, we diagnosed each of the components of the structure of civic competence: cognitive, behavioral and needmotivational, since these components are manifested in each individual in a different ratio. We see that, in general, the participants in the experiment have an average level of knowledge about the components of civic competence. This is due to the high qualifications of teachers of humanitarian subjects and the authority they enjoy with students. However, it is noteworthy that only a small number of students are interested in Uzbek and international news and events.

As for the behavioral component of civic competence, its low level should be noted. The process of assimilation and understanding by students of the concept of citizenship depends on the degree of their involvement in cognitive and socially useful activities. Students who have a fairly complete understanding of civic competence often do not see the possibilities of applying this quality in life, where their intervention and assistance is most needed. The inability to express oneself in significant practical activities for the benefit of society is an obstacle in the process of patriotic education. Students are inactive, indifferent to problems that go beyond their personal interests. In addition, the large percentage of students who use the global computer network and the quality of the information that comes to them are suggestive. It is obvious that the process of globalization, which is taking over the whole world, manifests itself on the Internet and influences the worldview of the modern student.

Also surprising is the decline in the role of television, which five years ago was the main mass media, and today is being replaced by the Internet. Newspapers are generally not taken into account as sources of information.

We ascertained the formation of the needmotivational component of civic competence using a questionnaire, in which we asked the participants of the experiment to write detailed answers. The importance of studying the history, traditions, customs of the Uzbek people is understood by most of the respondents, but they do not associate this knowledge with the importance of fulfilling a civic duty, for the good of the Motherland.

The results obtained determined the directions of work in the experimental groups:

1. Expand students' knowledge of politics, law, economics, culture.

2. To teach students to pay attention to the events taking place in the world, using the mass media, to critically assess the phenomena and events of the surrounding world, to understand the events within the country and around the world.

3. it is advisable to create pedagogical conditions for the development of a tolerant attitude towards representatives and manifestations of different cultures, the formation of intercultural communication skills.

4. It is necessary to lead students to understand the importance of learning a foreign language as a means of solving many problems of intercultural communication.

To solve these problems, the technology of civic education was used based on the model of the formation of socially active civic competence, 
CURRENT RESEARCH JOURNAL OF PEDAGOGICS 2(8): 63-67, August

2021 DOI: https://doi.org/10.37547/pedagogics-crjp-02-08-14

ISSN 2767-3278

(C)2021 Master Journals

Crossref do: 81 Google

Accepted $26^{\text {th }}$ August, 2021 \& Published 31 th August, 2021

revealing the potential of foreign language lessons.

The structure of civic education, as well as the formation of any moral quality, can be represented in a chain of successively arranged stages: the upbringing of patriotic feelings, the formation of knowledge, views and beliefs, the formation of a positive attitude to civic activities, the formation of practical skills necessary for the practical activities of a person for the good Homeland and in building friendly relations with other nations [2]. In foreign language lessons, each of these stages is filled with specific content.

The upbringing of feelings involves the creation of pedagogical conditions that evoke an emotional response from students. It includes developing a sense of affection, love, and devotion to one's hometown, hometown, and language. Students learn to see the manifestation of morality, courage, heroism, courage in the actions of people. Students are introduced to the concept of fairness in relations with people of other nationalities, trade, friendship, respect and tolerance. Teachers need to teach students to be critical of manifestations of antisocial character, irresponsibility, indifference, delinquency, predatory attitude towards nature, vandalism, nationalism, racism, chauvinism.

Among the main ways of forming knowledge, attitudes and beliefs are the following: enrichment of students with knowledge about the culture of their people, about the peculiarities of national cultures and the problems of their development. Students get acquainted with the state symbols, history, customs and traditions of Uzbekistan and the countries of the studied language.

The formation of a positive attitude towards socially active civic competence is to foster tolerance, internationalism, pride in their homeland. In foreign language lessons, students get acquainted with the biographies of prominent scientists, writers, public figures who have left a deep mark in the patriotic service of Uzbekistan, their people, as well as with biographies of foreign writers, politicians, representatives of science.

Practical skills and abilities are formed on the basis of knowledge that turns into personal beliefs only in the process of human activity. The organization of useful affairs of the pupil necessarily leads to his inclusion in multifaceted relationships with other people. Various situations that develop in the process of collective relations lead to certain actions, decisions, the choice of one or another line of behavior. It is necessary to emphasize the active nature of citizenship, which is manifested in the practical activities of a person and for the good of the Motherland, and in building friendly relations with other peoples.

Academic work is the most suitable form for the formation of socially active civic competence in students in foreign language lessons. Practice convinces that it is during the lesson that the foundations of multicultural consciousness, socially active civic competence are laid. The priority role of the lesson is due to the fact that it is in the lesson activity that the initial goals and objectives of education are set, basic concepts, ideas, ideals, knowledge of laws, theories, ideological and moral principles are formed.

The most suitable methods for the formation of socially active civic competence are the methods of verbal and emotional impact: story, explanation, conversation, debate, discussion and method of visual and practical impact - an example. Incentive methods serve to form a positive attitude towards civic activities: rewards, punishment and competition. The methods used to process practical skills and abilities are based on the practical activities of the students. All general methods for the formation of the necessary personality traits are: 
CURRENT RESEARCH JOURNAL OF PEDAGOGICS 2(8): 63-67, August

2021 DOI: https://doi.org/10.37547/pedagogics-crjp-02-08-14

ISSN 2767-3278

(C)2021 Master Journals

Crossref dof 81 Google

Accepted $26^{\text {th }}$ August, 2021 \& Published 31 th August, 2021

exercise, pedagogical requirement, accustoming, public opinion, assignment, educational situations [1].

When developing students' socially active civic competence in a foreign language lesson, it is advisable to use a system of educational means, which include: auditoriums, museums, monuments; educational and methodical complexes; visual aids; technical teaching aids; works of fine art and literature, various types of activities (play, educational, labor); pedagogical technique (speech, facial expressions, movements, etc.); mass media [3].

\section{Conclusion}

In conclusion, we came to the following conclusions that the applied technology:

1. Has a positive effect on the psychological climate in the experimental groups, interpersonal relationships of students, as they have additional common interests, students learn more about each other, show mutual respect;

2. Stimulates cognitive processes, encourages the study of the history, traditions of Uzbekistan and other countries, makes one take an interest in political, economic, cultural events around the world, use the media as sources of this knowledge;

3. Contributes to the improvement of the quality of knowledge of a foreign language, is an incentive to study it.

\section{REFERENCES}

1. Krivshenko L.P. Pedagogy: Textbook. -M.: Prospect, 2007. - $325 \mathrm{p}$.

2. Slastenin VA, et al. Pedagogy. -M.: Academy, 2007. - P. 174.
3. Kharlamov I.F. Pedagogy. -M.: Gardiriki, 2005. - $425 \mathrm{p}$.

4. MUKHIDDINOV, M., SULAYMONOV, I., KHASANOVA, M., ASLANOVA, K., \& SHOMURODOVA, S. (2021). Ode genre and ideological-artistic features of erkin vahidov's odes. Journal of Contemporary Issues in Business and Government, 27(3), 1317-1323.

5. Einfeld, A., \& Collins, D. (2008). The relationships between service-learning, social justice, multicultural competence, and civic engagement. Journal of college student development, 49(2), 95-109.

6. Муслихиддин, М. К. (2021). THE VIRTUE OF THE WORD. ALISHER NAVOIY XALQARO JURNALI, 1(1).

7. Vovchasta, N., Kozlovska, I., Opachko, M., Paikush, M., \& Stechkevych, O. (2021). The Use of Information and Communication Technologies as a Means of Professional Foreign Language Training. Revista Romaneasca pentru Educatie Multidimensionala, 13(3), 38-50.

8. Nazmiya, M. (2019). IDEALOGICALARTISTIC CONCERN IN THE CREATION OF KHUSROW DEHLAVI AND ALISHER NAVOI. Глобус, (9 (42)).

9. Muhitdinova, N. M. (2021). Interpretation of mystical themes in Mirhasan Sadoi and muhammad ghazi's collection of poems. Asian Journal of Multidimensional Research (AJMR), 10(3), 538-548.

10. Khairutdinova, M. R., \& Lebedeva, 0 . V. (2016). Developing the Multicultural Personality of a Senior High School Student in the Process of Foreign Language Learning. International journal of environmental and science education, 11(13), 6014-6024. 
CURRENT RESEARCH JOURNAL OF PEDAGOGICS 2(8): 63-67, August

2021 DOI: https://doi.org/10.37547/pedagogics-crjp-02-08-14

ISSN 2767-3278

(C)2021 Master Journals

Crossref dof 81 Google

Accepted 26 $6^{\text {th }}$ August, 2021 \& Published 31 ${ }^{\text {th }}$ August, 2021

11. Muhiddinov, M. (2005). The perfect man is the ideal of literature. Tashkent: Yangi asr avlodi, 206.

12. Talko, R., \& Samoylyukevych, I. (2020). The Formation of Communicative Competence in Primary-school Learners in L2 Lessons through Drama. Теорія і практика навчання іноземних мов. 